\title{
Managing Dualities in Organisational Change Projects
}

David Shaw, University of Greenwich Business School

Email: dshaw952@btinternet.com

The Version of Record of this manuscript has been published and is available in Journal of Change Management (15 December 2015) http://www.tandfonline.com/ DOI:

10.1080/14697017.2015.1118142.

\begin{abstract}
When managers want to change their organisation they often set up a project to do it, in the belief that doing so simplifies and focuses the change initiative and brings greater assurance of success. Case studies of three organisational change projects undertaken by Arts Council England during 2006-2007 are used to examine the notion of project management and change management as a duality. It is argued that the structured, systematic approach associated with project management needs to be balanced with the recognition of the complexities and uncertainties of organisational change associated with change management. Evidence from the case studies suggests the usefulness of this perspective, and indicates three subsidiary dualities that underlie this overarching duality. The first of these is focus and engagement - focusing on project tasks free from the distractions of day-to-day business and engaging with stakeholders to secure adoption of project results in practice. The second is tight governance and wide-ranging change - exercising tight governance of all change projects commissioned and commissioning enough change projects to make a real difference. The third is project management success and project success - achieving project-specific objectives and securing the longer-term and wider benefits that are sought through project-based working.
\end{abstract}

\section{Key words}

Organisational change project

Dualities

Stakeholder engagement

Complementarities

Project success

\section{Introduction}

When managers seek to change their organisation they frequently set up a project to do it. Traditional project management practice embodies what Graetz \& Smith (2010) describe as a 'linear, rational' approach to change, which has a natural appeal to managers who are under pressure to make specific commitments about what they will change, and how and by when they will change it. This runs counter, however, to the findings of change management writers such as Pettigrew (2012), who argue that managers inevitably have to 'transform strategy through use', and who reject the 
belief that organisational change can be reduced to linear sequences of planning and implementation. This paper seeks to extend current thinking on the role of project management in setting a clear direction for change, and providing systematic and structured methods for implementing it, through the notion of project management and change management as a duality. A growing body of literature advocates the notion of dualities (or polarities) as a way of balancing the strengths of apparently opposed management practices (Sanchez-Runde \& Pettigrew, 2003; Graetz \& Smith, 2010; Johnson, 2014). Sutherland \& Smith (2013) have identified a number of characteristics of dualities that can be observed in the combination of project management with change management. This duality involves simultaneously applying approaches that in significant ways are opposed to each other; it offers benefits of complementarities between the two different approaches; it encourages consideration of minimum thresholds of both project management discipline and responsiveness to the uncertainties of change that should be observed; it facilitates a dynamic approach to managing change as the tensions between the two approaches prevent the emergence of a 'balanced equilibrium'; and it encourages improvisation where that is beneficial rather than always treating deviations from an agreed project plan as signs of project management failure.

Drawing on the evidence of three case studies of change projects undertaken in Arts Council England (ACE) during 2006-2007, this paper identifies three dualities that underlie this overarching project management/change management duality, and examines how the context, processes and sequences of change influence the outcomes of managers' handling of these dualities. First, a project team can often achieve results because it can focus on a particular, difficult issue free from the distractions of the day-to-day business of other people in the organisation that is to change (Turner, 1999). At the same time, a project team has to engage with those other people if they are to be willing, effective participants in implementing change (Lundin \& Söderholm, 1995). Second, managers are expected to exercise tight governance of change projects, with the implication that they should not initiate so many that they cannot do this, because of the disruption that they cause among an organisation's normal authority and accountability relationships (Turner \& Keegan, 1999), the added burden of senior management decision-making to which they lead (Whitford, 2006), and the general problem of 'change overload' (Abrahamson, 2000; Herold et al., 2007). At the same time, Massini \& Pettigrew (2003) show that managers have to implement enough complementary change initiatives at the same time if they are to make a real difference. Third, 'good practice' in project management requires managers to specify at the outset what they expect each change project to achieve (Office of Government Commerce, 2009), and its success or failure can be judged by how far it meets those expectations (Larson \& Gobeli, 1987). At the same time, the extent to which a change project has been successful may be evaluated from a variety of different perspectives and at different points in time, and 'project management success' in producing the output specified in the project initiation document may not be the same thing as 'project success' (De Wit, 1988; Hughes, 2011). As Pettigrew (2012) points out, a change project may simply be one episode in a process leading to some more fundamental purpose, and successful achievement of the objectives of a particular project is only beneficial if it actually moves the organisation closer to attainment of that purpose. 


\section{Duality 1: Focus and engagement}

Advocates of project management methods often emphasise the distinctness of project-based work and the need to recognise this distinctness in the way it is organised. Mintzberg (1983) argues that, where the host organisation is the client for the outputs from projects, it should separate its projectbased work organisationally from its routine work in a dedicated 'administrative adhocracy', where its distinct characteristics and requirements can be better supported. Larson \& Gobeli (1987) argue that where matrix structures are adopted, the most effective organisational form is a 'project matrix' in which the project axis of the organisation has dominance over the functional axis. This latter perspective is in alignment with what Graetz \& Smith (2010) describe as the 'traditional change agenda', whereby a leader-centred model is adopted and 'dissident voices' are silenced.

Pettigrew (2012), however, argues that organisational change involves processes of legitimising and delegitimising ideas. If so, a project team cannot remain isolated but must engage actively with its stakeholders in order to legitimise its ideas in the minds of those who can influence their adoption. Lundin \& Söderholm (1995) conclude that episodes of 'planned isolation' of projects must be balanced by episodes of 'bridging' with the host organisation when the results of the projects are transferred to it. An emerging body of project management thinking is concerned with how projects should engage with their 'stakeholders', defined by Freeman $(1984,46)$ as 'any group or individual who can affect or is affected by the achievement of the organisation's objectives'. Nevertheless, in their study of references to stakeholders in academic writing on project management from 1984 to 2009 , Littau et al. $(2010$, p.9) observe only that 'the consideration of stakeholder theory is spreading within the project management research and practice world', and find that articles that develop, as opposed to simply referring to or applying stakeholder theory, are concentrated in the later years of their survey, from 2006 to 2009.

Hence the first key question is: How can managers combine focus on completing change project tasks with adaptation to stakeholders' emerging expectations? Leybourne (2006) points out that improvisation is liable to be frowned upon because it represents a departure from the linear process of planning and implementation that traditionally underlies project management, even though it is frequently practised. Managers may see benefits in improvising within an organisational change project if they can meet emerging stakeholder expectations by departing from an agreed project plan for completion of immediate project tasks.

\section{Duality 2: Tight governance and wide-ranging change}

Various writers (Turner \& Keegan, 1999; Whitford, 2006; Abrahamson, 2000; Herold et al., 2007) have highlighted the disruptive effects and strains on senior management capacity that arise when projects are overlaid across a traditional, functional organisation structure. The requirements for effective project governance (Office of Government Commerce, 2009) may appear to constrain the number of projects that can be managed.

Drawing on the ideas of Milgrom and Roberts (1995, p.181) about complementarities, however, defined as situations where 'doing more of one thing increases the returns to doing more of another', Massini \& Pettigrew (2003) show that successful organisational change requires action that is 'holistic', while adoption of 'singular solutions' that do not constitute cohesive programmes of complementary change initiatives is the hallmark of lower-performing organisations. In a survey of European firms, Fenton \& Pettigrew (2000) show that fewer than $5 \%$ of respondents were 
undertaking the most extensive and holistic range of change initiatives that they examined encompassing organisational structures, processes and external boundaries (e.g. use of strategic alliances and outsourcing) - but those few enjoyed a significant performance premium over others. This finding contradicts the simple proposition that firms must limit the number of projects undertaken in the interests of their governability.

Hence, the second key question is: How can managers balance the need for a minimum threshold of project governance capacity with the need for a minimum threshold of change initiatives to make a real difference? Strategies such as the proposal of Abrahamson (2000), that organisations should intersperse episodes of large-scale change with episodes of greater stability, may be needed to help strike this balance.

\section{Duality 3: Project management success and project success}

There are clear benefits to be gained from setting specific project objectives and then striving to achieve them. This perspective is reflected in the practice of documenting formally the objectives that a project is expected to achieve (Office of Government Commerce, 2009). McLeod et al. (2012) observe that the most widely-recognised criteria for evaluating a project's success are time, cost and quality, i.e. project outputs that meet the specifications defined at the outset of the project. De Wit (1988) defines success in these terms as 'project management success', distinguishing it from 'project success', which reflects the perspectives of a range of different stakeholders at different points in time. The perceived value of a change project may vary, depending on who evaluates it and when the evaluation is made (Pettigrew et al., 2001; Winter et al., 2006; McLeod et al., 2012).

Pettigrew (2012) highlights the problem of identifying what should be regarded as the outcome of a change project. There are widespread claims that the failure rate of organisational change projects is high. Hughes (2011), however, points out that the empirical evidence underpinning these claims is sparse, and that they beg the question of how their success or failure should be evaluated, from whose perspective, and at what point in time. As Pettigrew (2012) points out, a change project may be simply one episode in a process leading to some more fundamental purpose. Moreover, a formal project initiation document may be silent on some key roles of project-based organising. Organisations may adopt project management methods as a matter of policy in order to obtain benefits that are wider than those expected from any individual project, such as organisational learning from the experience of project-based working (Turner \& Keegan, 1999; Cooke-Davies, 2002). As De Wit (1988) and Pettigrew et al. (2001) point out, these considerations raise questions as to the credibility of evaluations that do not look beyond the specific objectives articulated in a project initiation document.

Hence the third key question is: How can managers both complete specified change project tasks and make progress with longer-term and wider organisational objectives? Project initiation documents place managers under pressure to produce the tangible outputs that they specify on time and within budget. Managers may need to demonstrate progress towards such project management success in order to maintain stakeholder support. They may also, however, need to demonstrate that the way they achieve that success will serve their organisation's longer-term and wider purposes. 
Project management and change management both offer useful insights into how managers can implement change, but in key ways they represent opposing perspectives. The three dualities identified above - focus and engagement, tight governance and wide-ranging change, and project management success and project success - embody key aspects of these opposing perspectives. The way in which managers deal with these dualities in practice is examined below through three comparative case studies of change projects in ACE.

\section{Change projects in Arts Council England: 2006-2007}

During the period of this research ACE, organised in functional hierarchies, was using project management methods to implement a range of organisational change projects. ACE managers believed that project management methods were helpful both in achieving desired organisational objectives and in encouraging cross-disciplinary working, helping make full use of the expertise available across their various sites, and facilitating teamwork and beneficial cultural change. ACE was restructuring its national office (its largest office in which the largest proportion of its senior managers were located) during this period, so it provided a unique opportunity to make a longitudinal study of the interplay between organisational change projects and their host organisation during a period of particular organisational fluidity.

Historically ACE had given closer attention to the 'supply side' of the arts, i.e. its roles in supporting artists and arts organisations whose work 'experts' regarded as 'excellent', than to the 'demand side', i.e. the role of ACE in meeting the expectations of a wide range of stakeholders including the general public. The three projects examined were all directed towards an organisational and cultural shift in favour of the 'demand side'. First, the Arts Debate project sought to investigate and incorporate in ACE's strategic plans what key stakeholders expected of public funding of the arts. Second, the Taking Part project set out to define an action plan for increasing attendance at and participation in the arts. Third, the Disability Equality Scheme project set out to achieve greater equality for disabled people as participants in and audiences of the arts and as employees of ACE itself.

After the period of this research Government funding was reduced, requiring it to restructure its organisation further. For example, ACE reported plans to reduce staff numbers by more than $20 \%$ from late 2012, to reduce the number of its most senior, executive director, positions from eight to four, and to reduce its property costs by $50 \%$ (Arts Council England, 2012). These sharp changes inevitably affected the longer term processes of change that these three projects were intended to initiate. The focus of this paper is on evaluation of the progress and prospects of these change projects during the period of this research when funding cuts on this scale were not yet contemplated.

\section{Research method}

There are distinguished precedents for the use of comparative case studies to examine how managers' approach to organisational change influences performance. For example, the major study by Pettigrew \& Whipp (1991) of how firms have managed strategic change and the influence of this on their competitiveness, used comparisons between firms with varying levels of performance to examine this relationship in four industry sectors. These case studies involved the collection and analysis of longitudinal data from the 1970s and 1980s through semi-structured interviews as well as review of documents from within the firms and published information about them. Similarly 
Pettigrew \& Whittington (2003) used comparative case studies of BP and Unilever to examine how firms have managed complementary change initiatives over time so as to raise performance. As Yin (2003) argues, the case study approach is well suited to collecting and analysing rich, longitudinal data as well as supporting the validation of research findings through triangulation between different techniques for collecting information - in this research semi-structured interviews, observation and document review.

ACE was selected as a suitable setting for this research because its managers were embarking on the implementation of major organisational changes, they were adopting project management methods to help implement those change processes, they were initiating a portfolio of projects which, together, were intended to bring about the strategic changes being sought, and at the same time they were managing their routine business within their normal, functional structures. As such ACE offered the opportunity to examine relationships (and the effects of those relationships) between project teams and their host organisation, between different projects within an overall portfolio of change projects, and between project-specific results and longer-term and wider change objectives. ACE constituted what Gray (2014) identifies as a critical case in that - in the presence of limited research resources - it provided a distinct opportunity to undertake a longitudinal study of the three dualities considered in this paper.

The three specific ACE projects that were examined as the units of analysis for this research were selected to achieve comparability in respect of the dimensions of interest (Gray, 2014). These projects constituted a distinct group that were all concerned with a common theme, i.e. reorientation of ACE's strategic priorities away from supporting 'excellence' as defined by 'experts' and towards meeting the expectations of a wider public. Moreover they were expected to represent projects with different approaches to balancing isolation from the host organisation with engagement with it, and focus on project-specific outcomes with concern for longer-term and wider change objectives. As such they reflected a 'deviant sampling' approach (Saunders et al., 2012; Gray, 2014). Furthermore, although they constituted three separate projects, there were clear interrelationships between them, so they provided the opportunity to examine how managers balance the requirement for tight governance with that to implement enough change projects to make a real difference.

Data were collected about these three projects over the course of the period September 2006 to December 2007. There were 28 semi-structured interviews with 19 different individuals. In line with the planned longitudinal nature of the study, nine people were interviewed twice, once in the autumn of 2006 and once in the summer of 2007. Bearing in mind the theoretical dimensions of interest, the sampling approach was mainly to select stakeholder voices that typified three distinct perspectives. First, national office participants in the projects were interviewed. Since all the projects were initiated by senior people in the national office, and led by managers in it, these interviewees were expected to provide distinct perspectives on the project management approach. Second, regional office participants were interviewed. Since the regional offices were responsible for managing ACE's relationships with the arts organisations that it funded, these interviewees were expected to provide useful perspectives on the engagement of the project teams with those members of the host organisation who would be expected to adopt the projects' results. Third, senior managers who were involved in the governance of the projects were interviewed. These managers were expected to provide useful information on ACE's approach to the governance of 
these projects, including the governance of their interrelationships with each other and with the host organisation. Some external stakeholders in ACE were interviewed also, but the role of external stakeholders was limited by the small number of them with sufficiently detailed knowledge of the projects to provide useful information on the issues being examined. Overall interviews were conducted with 11 national office and four regional office staff, and with four external stakeholders.

One project meeting was observed in relation to each of the three projects. Overt non-participant methods were used. This facilitated triangulation on the results of the interviews because, as Arksey and Knight (1999) observe, there may be differences between what people say they do and what they actually do in a decision-making meeting. Use of this method also extended the scope of the research to include some project team members who were not interviewed.

A range of documents were reviewed, including project documents relating to the three projects being examined, documents relating to ACE's strategies, policies and organisation, and publications about ACE by researchers and other commentators. These were reviewed critically, bearing in mind that, as Hakim (2000) points out, having been prepared for other purposes they might not be entirely dependable as a source for this research. For example while the official history of the Arts Council of Great Britain by Sinclair (1995) was used as a source of contextual information this was considered alongside independent sources such as the 'Alternative History' by Witts (1998).

Thematic analysis was used to identify patterns within the data (Braun \& Clarke, 2006). First, initial ideas were developed through review of the data. While maintaining openness to surprises within the data, these ideas were influenced by the insight of Pettigrew \& Whipp (1991), that change is the outcome of the interplay between its content, context and process, and at the same time by the insight of De Wit (1988), that the success or otherwise of a change project may legitimately be considered from a variety of different stakeholder perspectives and at different points in time. Thus, analytical questions about the content, context, process and outcomes of change projects influenced the whole of the data collection and analysis process. Second, codes were developed based on interesting features within the data, and comparative analysis of the entire data set in relation to the three cases was undertaken using these codes. Thus, for example, three codes were used to analyse the data about project outcomes. These were 'project-specific outcomes', i.e. the extent to which outcomes specified in a project initiation document were attained; 'associated outcomes', i.e. the extent to which the project-based work made contributions towards organisational learning, and towards cultural integration across ACE; and 'potential outcomes', i.e. the extent to which contributions had been made towards the longer term purposes towards which the projects had been directed, as reflected for example in project results beginning to be adopted in practice. Third, themes were identified, with some codes appearing to constitute themes in their own right while others formed elements of themes. Thus, 'resourcing of the project governance function' emerged as a major theme in its own right, whereas 'integration of national and regional office staff' in project teams was subsumed within the broader theme of project engagement with the host organisation. Fourth, these themes were reviewed to check their validity in relation to the entire data set. Finally, each theme was refined and its meaning in relation to the research clarified. 


\section{Findings from the three case studies}

Findings from the three case studies are set out in the following paragraphs. These reveal significant differences in the way in which these three dualities were managed in the three projects. Data from the research that highlight these differences are in the table below.

Table 1: Key points of comparison between the three projects

\begin{tabular}{|c|c|c|c|}
\hline Dualities & Arts Debate & Taking Part & $\begin{array}{l}\text { Disability } \\
\text { Scheme }\end{array}$ \\
\hline $\begin{array}{l}\text { Focus \& } \\
\text { engagement }\end{array}$ & $\begin{array}{l}\text { 'Everybody had a sense } \\
\text { that over the next six } \\
\text { months this is part of my } \\
\text { job.' } \\
\text { - ACE was clear that } \\
\text { there should be a } \\
\text { sharp focus on } \\
\text { completing all project } \\
\text { tasks within a } \\
\text { specified timescale. }\end{array}$ & $\begin{array}{l}\text { 'The level of } \\
\text { conversations about what } \\
\text { Taking Part is has } \\
\text { increased ... tenfold, } \\
\text { twentyfold. } \\
\text { unbelievable.' } \\
\text { - The project engaged } \\
\text { with stakeholders } \\
\text { across ACE from the } \\
\text { outset, as well as } \\
\text { tackling project tasks. }\end{array}$ & $\begin{array}{l}\text { 'I don't think the Disability } \\
\text { Equality Scheme } \\
\text { Implementation Team } \\
\text { was quite right.' } \\
\text { - The project focused } \\
\text { sharply on completing } \\
\text { its tasks. An attempt } \\
\text { was made to involve a } \\
\text { wider stakeholder } \\
\text { group but it failed. }\end{array}$ \\
\hline $\begin{array}{l}\text { Tight } \\
\text { governance \& } \\
\text { wide-ranging } \\
\text { change }\end{array}$ & $\begin{array}{l}\text { 'This was all [the Chief } \\
\text { Executive's] idea. [He is] } \\
\text { the driving force behind } \\
\text { it.' } \\
\text { - The Chief Executive's } \\
\text { commitment partly } \\
\text { filled a gap in project } \\
\text { governance capacity. }\end{array}$ & $\begin{array}{l}\text { 'I think ... we had ... } \\
\text { underestimated the } \\
\text { decision processes'. } \\
\text { - Decision-making } \\
\text { about the project } \\
\text { proved more tentative } \\
\text { than some expected, } \\
\text { reflecting shortage of } \\
\text { governance capacity. }\end{array}$ & $\begin{array}{l}\text { 'I think we need more } \\
\text { leadership in the } \\
\text { organisation in terms of } \\
\text { our messages...' } \\
\text { - Project team } \\
\text { members perceived a } \\
\text { gap in terms of senior } \\
\text { level governance. }\end{array}$ \\
\hline $\begin{array}{l}\text { Project } \\
\text { management } \\
\text { success \& } \\
\text { project } \\
\text { success }\end{array}$ & $\begin{array}{l}\text { 'We weren't under any } \\
\text { pressure from the } \\
\text { [Government]'. } \\
\text { '[Research findings from } \\
\text { the Arts Debate are] being } \\
\text { factored into the } \\
\text { corporate planning } \\
\text { process in a way that I } \\
\text { hadn't expected'. } \\
\text { - ACE was free to } \\
\text { pursue its objectives } \\
\text { without external } \\
\text { pressure. lack of } \\
\text { Despite a lagement } \\
\text { active engagem wider } \\
\text { with the other } \\
\text { organisation, } \\
\text { factors contributed to } \\
\text { early uptake of the } \\
\text { project's results. }\end{array}$ & $\begin{array}{l}\text { '[The project will help] to } \\
\text { identify gaps ... in ... } \\
\text { current activity to address } \\
\ldots \text { the Public Service } \\
\text { Agreement Targets', but 'I } \\
\text { don't think [Government } \\
\text { influence] honestly did } \\
\text { make a difference to the } \\
\text { direction we went.' } \\
\text { '[Everybody is saying], } \\
\text { "yes, we need to change; } \\
\text { yes we need to take it } \\
\text { seriously this time."' } \\
\text { - ACE was under } \\
\text { pressure to focus on } \\
\text { the Government's } \\
\text { targets, but it also } \\
\text { pursued longer term } \\
\text { objectives. } \\
\text { People across ACE } \\
\text { readily engaged with } \\
\text { the project's results. }\end{array}$ & $\begin{array}{l}\text { 'There's a legal } \\
\text { requirement. We have to } \\
\text { do this work.' } \\
\text { - ACE subordinated its } \\
\text { longer term objectives } \\
\text { in 'mainstreaming' } \\
\text { disability equality to } \\
\text { achieving statutory } \\
\text { compliance. }\end{array}$ \\
\hline
\end{tabular}




\section{The Arts Debate}

ACE's plan for the Arts Debate project was first to focus sharply on completion of project tasks, and only after those tasks had been completed to engage actively with the organisation as a whole on the outputs from the project. As one informant put it, '... the Arts Debate was very clear, we were launching in November [2006], we were closing in May, we were doing the analysis in the summer, we were reporting in October [2007]...'.

This initial priority of completing project tasks efficiently was reflected in the composition of the project team. A professional, full-time project manager was appointed to support the project on a fixed-term contract, which imposed a clear deadline for completion of the project. Other team members were drawn from just two groups within ACE's national office, its communications and research teams, whose expertise was closely aligned with the project requirements. This approach, however, was disrupted when the national office review led to one key member of the team leaving the organisation. At this point a regional office staff member was appointed to the team. Initially there was concern among the original team members about involving an 'outsider'. This was partly because of a concern that this might distract the original, cohesive national office team from its focus on what needed to be done, and partly because the team leader might have less influence over a regional office staff member in ensuring that the required work would be completed on time. As one informant put it, '... we were very concerned about it ... we couldn't go and bark at them when we needed to ...'. It nevertheless came to be recognised that this new team member both performed the required tasks effectively and brought to the team the advantage of ready acceptance by other regional office staff members.

The initial focus on completing project tasks proved effective. It was reported that, '... everything we said we'd do we've done with a couple of exceptions ...'. By the end of the period of this research, however, it was recognised that action to engage with the organisation as a whole on the results of the project was an essential next step. One project participant said, '... what we haven't done yet is roll out what the Arts Debate has meant across the organisation as a whole ... we will need to do that.'

This approach, involving an initial episode of focus on project tasks, to be followed by an episode of stakeholder engagement, might have been expected to present problems. It might initially have undershot a minimum threshold of stakeholder engagement. Two main factors, however, helped to alleviate such problems. First, as discussed below, other complementary initiatives were in progress that supported and sustained the Arts Debate project. Second, ACE's Chief Executive was the initiator and sponsor of this project, which both helped ensure strategic fit between this and other initiatives being taken by ACE at the time, and placed the project team in a strong position to secure the organisational support that it needed. As one informant put it, '.. [the Chief Executive] is $100 \%$ behind this ... if people don't like [it] it's sort of tough ...'.

During the period of this research ACE was undertaking some 30 projects concerned with accomplishment of its corporate plan. While there could be little doubt that ACE was at the time undertaking enough change projects to make a real difference, there was a question as to whether it was undershooting the minimum threshold for capacity to govern them. During an earlier restructuring in 2002-2003, when ACE was being formed through the merger of the former Arts Council of England with 11 Regional Arts Boards, ACE had set up a senior management body to 
govern its restructuring projects. ACE decided, however, to disband this body on completion of that restructuring because it could not sustain the level of senior management resources involved. Subsequent projects were governed by ACE's Management Committee, the senior management body responsible for the direction of all of ACE's business. The Management Committee had insufficient time to give more than limited attention to ACE's projects. One Management Committee member said:

If you look at the sum total of what Management Committee does in relation to corporate projects, it's quite a small proportion of how its time is taken up ... it's only a part of Management Committee's time. [The] last progress report [on corporate projects] came to us early this month. It was a 10 or 15 minute item on the agenda, which was actually about as generous as it gets I'm afraid. It's limited.

Unsurprisingly, one participant in the Arts Debate project observed that '... I think the whole corporate projects approach has suffered for want of [a] central coordinating role.' Nevertheless the Chief Executive's sponsorship helped ensure sufficient collaboration with other activities across the organisation to underpin its success. In particular, the restructuring of ACE's national office led to changes in that office's membership and organisation design that reflected the desired shift in priorities that underlay the Arts Debate project, and also the Taking Part and Disability Equality Scheme projects.

Many individuals were declared potentially redundant as a result of the national office review, and had to apply for new positions in order to remain in the organisation. One informant explained that, in contrast with previous restructurings in ACE, the way in which the restructuring was managed facilitated the departure of people who were out of sympathy with the organisation's direction of change:

... we've taken a very de minimis approach to migrating people into the new structure ...what we did is to give people the choice, you can choose to join this new structure ... whereas ... what happened with [previous restructurings] is that some people didn't really have the choice to be made redundant ....

Many of the national office's senior managers left the organisation during this period, including two executive directors and all of its art form directors. The reorganisation of the national office underpinned ACE's new strategic priorities by integrating organisationally 'supply side-focused' and 'demand side-focused' functions. As one informant expressed it:

It's the first time we've got development and the arts in one team. Historically it would have been about us getting a balance between those two things and now we're having to come up with recommendations ... where we've agreed things.

While the number of change projects being undertaken during this period clearly threatened to swamp the resources for governing them, implementation in parallel of a number of initiatives directed towards similar outcomes, including in particular the national office review, clearly provided benefits as a result of complementarities between them.

As noted above, the Arts Debate's sharp focus on completing project tasks was effective in achieving 'project management success'. Complementarities between other initiatives and the Arts Debate 
project, as well as active sponsorship by the Chief Executive, also helped secure the potential for 'project success' in the longer term. ACE was in addition seeking other, longer term objectives from its use of project management methods, including stronger integration across the recently merged organisation with more cross-disciplinary working, and organisational learning through the project experience of those who were involved in project-based work. In this case losses of project team members as a result of the national office review and the fixed-term nature of the project manager's appointment constrained the Arts Debate's success from this perspective.

\section{Taking Part}

In contrast with the Arts Debate project, the Taking Part project team gave priority to engaging with stakeholders across the organisation from the outset. Involving people from ACE's regional offices in the project team itself was a priority because they managed the relationships with the arts organisations that ACE funded. As such they were responsible for practical action to increase participation in the arts. As one project participant put it, 'we have to go through this because we have 600 staff, and ... it won't make a difference unless we get all of our staff aligned and doing the work ...'. Three members of the project team (one third of the total) were drawn from the regional offices, working on the project on a part-time basis. A key enabler of this approach was the availability of people across ACE's regional offices, as well as in the national office, whose day-to-day responsibilities were concerned with participation in the arts. This made it possible to form a project team with the knowledge and expertise to complete project tasks efficiently that also included people from a range of different offices. One project team member observed that:

It felt like a really good mix of regional people and national people, and people who'd worked on the arts side and people who were more on the policy side, and people who got community art ... [we] couldn't have done it without that.

The leadership style of the team leader facilitated inclusion of people from across the organisation. One team member said that the project leader '... does facilitate in a really good way, so that everybody has their view, and that actually everybody does take responsibility for different pieces of work... It was ... a very cooperative environment to work within...'. The way in which the objectives of the project were defined, which is discussed below, was also a key factor in securing commitment to it. Whereas the Arts Debate project involved an episode of focus followed by an episode of engagement, focus and engagement operated in parallel throughout this project.

As in the case of the Arts Debate, the national office review complemented the Taking Part project by restructuring the national office in ways that reinforced its objectives. Nevertheless, the shortage of capacity to govern ACE's projects is likely to have inhibited fully effective action to secure benefits from complementarities between the Taking Part and other projects. In particular, despite the concern of the Taking Part project with increasing participation in the arts among disabled people, this project and the Disability Equality Scheme project appear to have been managed largely as separate initiatives. While some benefits from complementarities were obtained, the inadequacy of ACE's project governance capacity constrained the level of these benefits.

The Taking Part project provided means whereby ACE could respond to the Government's specific, time-bound public service agreement targets in this sector, which involved increasing participation in the arts among black and minority ethnic people, disabled people, and people on low incomes. ACE's Government funding was directly linked with its contribution towards meeting these targets, 
so achieving them might have been expected to be the sole or primary objective of the Taking Part project. In fact ACE defined the project's objectives in broader terms, because it believed that focusing on these targets alone would not have been the most effective way of increasing participation in the arts. This appears to have been important in mobilising commitment across the organisation to objectives that were seen as being more worthwhile in the long term. One interviewee said:

One of the main conclusions quite early on was this was seen as a Government agenda rather than as something that we owned, which is why, to make it make sense, we had to park the current targets, and just [consider], what is appropriate, and where could the Arts Council have influence, and to some extent what's morally appropriate as well actually?

At the end of the period of this research, 'project success' as well as 'project management success' were already clearly in prospect as a result of explicit efforts by the project team to address the requirements for both. One project participant highlighted the impact of the efforts made to engage with people across the whole organisation: '...it's made something stick ... within the corporate planning process Taking Part was instantly at the top of everybody's agenda ...'. Moreover, participation in the project appeared to have achieved much in adding to the organisation's learning and social capital. One project team member said that:

It's certainly made my relationships with colleagues, both around the organisation and at national office, much stronger, through ... having to thrash out some quite meaty issues together... the project is so tied in with the ... role that I have ... the work I've done on the project has actually informed the way that I'm working ....

\section{Disability Equality Scheme}

The Disability Equality Scheme project had its origins in a Disability Equality Strategy project that was launched in 2003 with the long-term objective of 'mainstreaming' disability equality across the organisation. The focus of the project was, however, altered by the Disability Discrimination Act 2005. This Act placed a statutory duty on ACE to produce a Disability Equality Scheme by the end of 2006, with subsequent preparation and implementation of an action plan to give effect to the Scheme. The emergence of a statutory duty on ACE to produce certain specified outputs within a defined timescale had the effect of shifting attention sharply towards compliance with it, with the national office diversity department in the lead on the tasks to be completed, and away from other priorities, including engaging widely with stakeholders across the organisation.

A cross-structural project team, the Disability Equality Scheme Implementation Team, was formed at the beginning of 2007, which should have provided a mechanism for wider involvement across the organisation as a whole. This project team proved ineffective, however, and was disbanded soon after it was formed. One of those involved said that:

We're rethinking it completely. They started off [meeting] fortnightly, and then we went to monthly to try and help people round ... time management, and then we were finding that there was a small hard core of people turning up ... and the others were kind of flitting in and out ..... 
As discussed below, the shift in the focus of the project towards meeting near-term, statutory requirements appears to have discouraged engagement with the project across the organisation.

The Disability Equality Scheme project, as the other two, had better prospects for successful implementation because of the influence of the national office review on the national office's membership and organisation design. Some benefits of complementarity that might have been expected, however, in particular with the Taking Part project, were not achieved. This project in particular exposes the weakness of ACE's project governance arrangements at this time. It should not have been commissioned as a cross-structural project if all it was to do was to produce a Disability Equality Scheme to comply with ACE's statutory obligations, and an action plan to support its implementation, because all the necessary expertise to do this lay within the national office's diversity department. If on the other hand priority was to be given to the objective of 'mainstreaming' disability equality across ACE, the project should have been set up differently, and with stronger governance of its relationship with the Taking Part project.

The refocusing of the Disability Equality Scheme on producing the outputs required by the Disability Discrimination Act 2005 was effective in securing a high degree of 'project management success'. One project participant said that '... we are seen as one of the leading, if not the leading organisation in this ... [the Disability Rights Commission] have been quoting our work'. Nevertheless, the wider objective of 'mainstreaming' disability equality across the organisation was far from being met during the period of this research. As one participant in the project said, '[we have done nothing more] than to put a toe in the water'. The relative outcomes of the project as regards 'project management success' and 'project success' were the result of deliberate decisions to focus on statutory compliance. This refocusing of the project is likely to have inhibited wider engagement across the organisation as a whole. Whereas the Taking Part project had proved effective in capturing the enthusiasm of people across ACE for its objective of increasing inclusion in the arts in the long term, production of the outputs required to comply with the Disability Discrimination 2005 Act did not do so.

\section{Discussion}

The data set out in Table 1 illustrate how the dualities identified were managed in different ways across the three projects. Managers recognised the need for both focus and engagement in all the projects, but the approach was primarily sequential in the Arts Debate and Disability Equality Scheme projects while it was primarily contemporaneous in the Taking Part project. ACE was undertaking wide-ranging change, but while the direct involvement of the Chief Executive made for some tightness in the governance of the Arts Debate project, governance of the other two projects was comparatively loose. Various factors contributed to the project success as well as the project management success of the Arts Debate project and, where the attention paid to longer term project success was particularly sharp, the Taking Part project, whereas the main focus of the Disability Equality Scheme project during the period of this research was on project management success. The implications of these different approaches to managing the dualities are discussed below.

\section{Duality 1: Focus and engagement}

Comparisons between the three case studies in relation to the duality, focus and engagement, drawing on data from the research, are set out in the table below. 
Table 2: Focus and engagement

\begin{tabular}{|c|c|c|}
\hline Projects & Informants' Comments & Observations \\
\hline Arts Debate & $\begin{array}{l}\text { '... the Arts Debate was very clear, we } \\
\text { were launching in November [2006], } \\
\text { we were closing in May, we were } \\
\text { doing the analysis in the summer, we } \\
\text { were reporting in October [2007]...' } \\
\text { '... we were very concerned about [a } \\
\text { regional office staff member joining } \\
\text { the team] ... we couldn't go and bark } \\
\text { at them when we needed to ...' } \\
\text { 'The only way it will work is by } \\
\text { ensuring that the projects ... are } \\
\text { genuinely corporate projects, not ... } \\
\text { national office projects' }\end{array}$ & 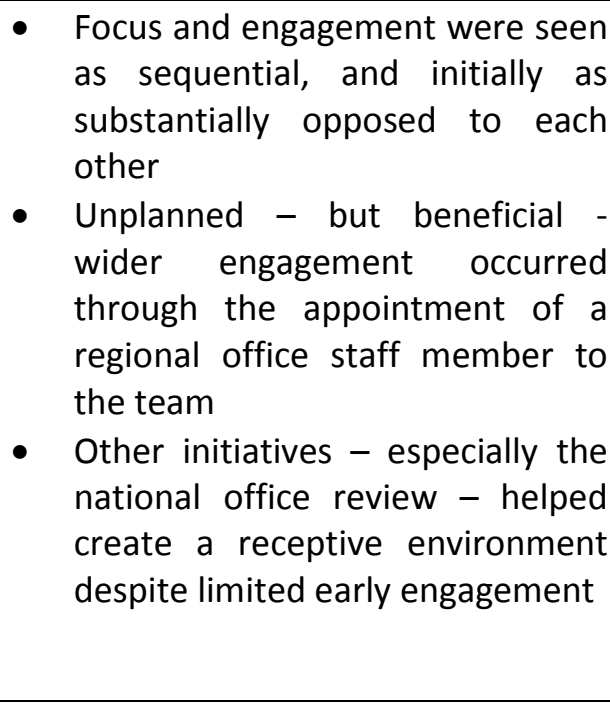 \\
\hline Taking Part & $\begin{array}{l}\text { 'We have to go through this because } \\
\text { we have } 600 \text { staff, and ... it won't } \\
\text { make a difference unless we get all of } \\
\text { our staff aligned and doing the work } \\
\text {..' } \\
\text { 'It felt like a really good mix of } \\
\text { regional people and national people... } \\
\text { [we] couldn't have done it without } \\
\text { that' }\end{array}$ & $\begin{array}{l}\text { - Focus and engagement were } \\
\text { pursued simultaneously and seen } \\
\text { throughout as largely } \\
\text { complementary } \\
\text { - Availability of regional office staff } \\
\text { with relevant expertise facilitated } \\
\text { this approach }\end{array}$ \\
\hline $\begin{array}{l}\text { Disability Equality } \\
\text { Scheme }\end{array}$ & $\begin{array}{l}\text { 'The Disability Equality Duty not only } \\
\text { says what you need to have in a } \\
\text { Scheme ... but it also tells you how } \\
\text { you have to do that.' } \\
\text { 'We were finding that there was a } \\
\text { small hard core of people turning up } \\
\ldots \text { and the others were kind of flitting } \\
\text { in and out ....' }\end{array}$ & $\begin{array}{l}\text { - Focus on compliance with } \\
\text { statutory obligations was seen as } \\
\text { paramount } \\
\text { - Efforts to engage with a wider } \\
\text { stakeholder group was inhibited } \\
\text { by this priority }\end{array}$ \\
\hline
\end{tabular}

The evidence from these case studies shows the benefits of protecting a project team from the distractions of its host organisation in making progress with project-specific tasks. The data set out in Table 2 show how the managers of the Arts Debate project focused from the outset on producing specific outputs within a defined timescale and that, despite their unplanned inclusion of a regional office staff member in the team part-way through the project - an improvisation that helped the project to engage with its host organisation - they gave priority to protecting the project team from the distractions of the wider organisation. ACE's Chief Executive, through his personal sponsorship of the project, gave the team authority to do whatever was needed to complete its work successfully. The focus of the Disability Equality Scheme project on statutory compliance that is illustrated in Table 2 led to managers in ACE's national office diversity department undertaking most of the work, with only limited involvement of people from other parts of the organisation, and this also paid off in terms of the progress made with project-specific tasks. 
A number of writers have highlighted the drawbacks of isolation of project-based work and limitations on how far the project axis of an organisation should have primacy over its functional axis. Gann \& Salter (2000) highlight the risks that project teams may become too internally cohesive and too committed to their project-specific objectives to remain focused on the overall objectives of their parent organisations in commissioning their work. Other writers (Galbraith, 1971; Turner \& Keegan, 1999) counsel against giving primacy to the project axis of a matrix structure wholesale where the functional axis of the organisation may also have key roles. Moreover, neither isolating projects from their host organisation nor giving them the authority to override organisational barriers to their success addresses the need that Pettigrew (2012) identifies to legitimise and delegitimise ideas when managing organisational change processes. ACE's managers recognised this, and planned much increased engagement with stakeholders in these projects across the organisation once the project-specific tasks had been completed. Their approach was consistent with the conclusion of Lundin \& Söderholm (1995), that periods of isolation of a project team while it completes its project tasks must be balanced with episodes of engagement so as to embed the project results in the organisation's ways of working.

The Taking Part project, just as the other two, made good progress in completing project-specific tasks. As indicated in Table 2, ACE's managers included three regional office staff members in the project team as a key means of engaging with its regional office stakeholders, and the availability of regional office staff with relevant expertise and interests enabled the project team to include a wider stakeholder group without compromising its ability to focus effectively on project tasks. Thus the Taking Part project embedded stakeholder engagement in its ways of working from the outset, whereas the Arts Debate and Disability Equality Scheme project teams recognised that a period of relative isolation would have to be balanced with a subsequent period of engagement. Taken together, these case studies illustrate the necessity for both focus (in line with a traditional project management perspective) and engagement (in line with a broader, change management perspective), but different ways in which managers may balance the two.

The way in which this duality played out was influenced by a range of contextual factors. The role of the national office review complemented all three projects by changing the membership and organisation design of ACE's national office in ways that would facilitate commitment across the organisation to the outputs from them. This complementarity mitigated the effects of the limited engagement of the Arts Debate and Disability Equality Scheme project teams with stakeholders across the organisation as a whole. The ACE Chief Executive's role in sponsoring the Arts Debate project contributed to that project's prospects of acceptance and support. The presence of people with expertise in encouraging participation in the arts in all ACE's regional offices presented an opportunity to include a range of stakeholders in the Taking Part project team without prejudicing the capability of the team to complete its assigned tasks, whereas the nature of the work required in the other two projects potentially involved making trade-offs between wider engagement and capacity to complete assigned tasks. Comparison of the Taking Part and Disability Equality Scheme projects suggests that the way in which projects handle external pressures to meet particular targets makes a difference to the willingness of stakeholders to engage with them. The decision of the Taking Part project team to pursue wider and longer term objectives than the public service agreement targets that they were accountable for helping to achieve appears to have contributed to stakeholders' willingness to engage with it, whereas the Disability Equality Scheme project team's decision to focus primarily on compliance with ACE's statutory obligations contributed to the weak 
engagement with it outside the specific diversity community within ACE. Thus managers' options in balancing the opposing elements of the duality appear subject to influence from the context in which they are played out.

\section{Duality 2: Tight governance and wide-ranging change}

Comparisons between the three case studies in relation to the duality, tight governance and wideranging change, drawing on data from the research, are set out in the table below.

Table 3: Tight governance and wide-ranging change

\begin{tabular}{|c|c|c|}
\hline Projects & Informants' Comments & Observations \\
\hline Arts Debate & $\begin{array}{l}\text { 'If this had not been something that } \\
\text { [the Chief Executive] was driving ... I } \\
\text { think some of those [obstacles] may } \\
\text { have been more of an issue' } \\
\text { 'It's the first time we've got } \\
\text { development and the arts in one } \\
\text { team.' }\end{array}$ & $\begin{array}{l}\text { - Personal sponsorship by the Chief } \\
\text { Executive helped fill the } \\
\text { governance gap for this project } \\
\text { - Simultaneous pursuit of other } \\
\text { initiatives, in particular the } \\
\text { national office review, } \\
\text { contributed benefits from } \\
\text { complementarities between } \\
\text { those initiatives and all three of } \\
\text { the projects examined, despite } \\
\text { constrained governance capacity }\end{array}$ \\
\hline Taking Part & $\begin{array}{l}\text { 'When we started off with corporate } \\
\text { projects ... we ... had ... a project office } \\
\ldots \text { We had that dedicated resource to } \\
\text { coordinate and manage these } \\
\text { interrelationships, in particular } \\
\text { between projects and then with the } \\
\text { organisation. Now we look back } \\
\text { nostalgically on those days, because, } \\
\text { although of course the resource } \\
\text { pressure wouldn't necessarily have } \\
\text { permitted us to retain an executive } \\
\text { director dedicated in that way ... I } \\
\text { think the whole corporate projects } \\
\text { approach has suffered certainly for } \\
\text { want of that central coordinating } \\
\text { role'. }\end{array}$ & $\begin{array}{l}\text { - Lack of resources for project } \\
\text { governance affected decision- } \\
\text { making, particularly regarding this } \\
\text { and the Disability Equality Scheme } \\
\text { project their } \\
\text { interrelationships and } \\
\text { - ACE's learning from prior } \\
\text { experience may nevertheless } \\
\text { have helped it to secure benefits } \\
\text { from its use of project } \\
\text { management methods }\end{array}$ \\
\hline $\begin{array}{l}\text { Disability Equality } \\
\text { Scheme }\end{array}$ & $\begin{array}{l}\text { 'I don't think the Disability Equality } \\
\text { Scheme Implementation Team was } \\
\text { quite right.' } \\
\text { 'I think we need more leadership in } \\
\text { the organisation in terms of our } \\
\text { messages...' }\end{array}$ & $\begin{array}{l}\text { - With greater governance } \\
\text { resources ACE might have } \\
\text { decided against commissioning } \\
\text { this project in the form in which it } \\
\text { actually emerged } \\
\text { - Some potential benefits from } \\
\text { complementarities between this } \\
\text { and the Taking Part project in } \\
\text { particular were not secured }\end{array}$ \\
\hline
\end{tabular}

At the time of this research ACE was engaged in an ambitious programme of organisational change involving many change projects, only three of which were examined in this research. Having recently 
been created as an integrated organisation, following the merger of 12 separate organisations, it was in the process of changing its strategic direction and implementing associated organisational changes. Despite the scale of this change programme ACE had rowed back from the heavy investment in project governance that it had made during its immediate post-merger integration in 2002-2003. The data in Table 3 illustrate the consequences of this for the Disability Equality Scheme project in particular, which arguably should not have been commissioned in the form in which it emerged. Either the national office's diversity department should have produced the required outputs within ACE's normal functional structure without recourse to project management methods, or the project should have been defined in ways designed more explicitly to capture the benefits of complementarities with other, related initiatives.

Pettigrew, Woodman \& Cameron (2001) argue that 'whole-system' change, encompassing structures, processes and boundaries, produces superior performance as a result of complementarities between the different change initiatives involved, whereas 'part-system' change not only fails to produce these benefits but is liable actually to worsen performance. Effective implementation of 'whole-system' change seems to imply the need for tight governance of the overall programme of change, as the Office of Government Commerce advocates (2009). Abrahamson (2000) and Herold et al., (2007) highlight the change overload experienced by employees in 'turbulent' change environments, and the absence of tight governance seems liable to aggravate that sense of turbulence.

The impact of the limited project governance resource provided during this period, however, should be set in a wider context. ACE's heavy investment in project governance a few years before had left a legacy in terms of its managers' understanding of how to make change projects work, both individually and in combination. Arguably, the need for substantial project governance capacity was for this reason less in 2006-2007 than it had been in 2002-2003. Moreover, despite the lack of tight project governance during the period of this research, there was a clear, strategic coherence to the portfolio of change projects being undertaken, which is reflected in particular in the consistency of direction of the three projects examined in this research, and the complementarities between all of them and the national office review. The sense of turbulence that ACE staff experienced is likely to have been mitigated by the cohesiveness of the projects being undertaken. So far as the Arts Debate project in particular is concerned, the data in Table 3 illustrate how the Chief Executive's sponsorship of it went a considerable way towards mitigating the lack of a well-resourced programme governance body.

During the period of this research, when ACE faced the need to continue to transform itself, its managers chose to pursue a range of change initiatives that was wide enough to make a real difference, despite their conclusion that their earlier level of investment in project governance was no longer sustainable. The context within which they were working in 2006-2007 facilitated this, including the expectation that this period of ambitious change would be followed by a period of consolidation. As Abrahamson (2000) argues, interspersing episodes of large-scale change with episodes of greater stability may be a solution to providing sufficient project governance in the face of resource constraints.

Managers may not need to provide an ideal level of resource for project governance (from a traditional, project management perspective) in order to secure benefits from a holistic programme 
of complementary change projects (as identified in the wider, change management literature). Benefits were obtained from complementarities between the national office review and all of the three projects examined, despite limited, active governance of their interrelationships. A high degree of strategic coherence across the portfolio of change projects undertaken may reduce the minimum threshold for provision of project governance.

\section{Duality 3: Project management success and project success}

Comparisons between the three case studies in relation to the duality, project management success and project success, drawing on data from the research, are set out in the table below.

Table 4: Project management success and project success

\begin{tabular}{|c|c|c|}
\hline Projects & Informants' Comments & Observations \\
\hline Arts Debate & $\begin{array}{l}\text { 'Everything we said we'd do we've } \\
\text { done with a couple of exceptions' } \\
\text { '[The Government] didn't particularly } \\
\text { influence us that much... it was a } \\
\text { priority to make sure [the } \\
\text { Government] was comfortable with } \\
\text { what the Arts Debate was doing, but } \\
\text { we were still going to do this, and do } \\
\text { it in a way we wanted to do it' } \\
\text { '[Findings from the Arts Debate are] } \\
\text { being factored into the corporate } \\
\text { planning process in a way that I } \\
\text { hadn't expected [by this stage]' }\end{array}$ & $\begin{array}{l}\text { - The initial focus was on project } \\
\text { management success } \\
\text { - ACE, not the Government, set the } \\
\text { project objectives, which helped } \\
\text { gain the organisation's support } \\
\text { - The project was beginning to have } \\
\text { a longer-term impact, partly } \\
\text { because of the Chief Executive's } \\
\text { commitment } \\
\text { - Organisational learning from the } \\
\text { experience of undertaking this } \\
\text { project was constrained by losses } \\
\text { of project team members from } \\
\text { the organisation }\end{array}$ \\
\hline Taki & $\begin{array}{l}\text { 'It felt like a very effective team ... } \\
\text { people were off doing work ...' } \\
\text { 'I don't think [the Government] } \\
\text { honestly did make a difference to the } \\
\text { direction we went' } \\
\text { 'There's a level of understanding } \\
\text { amongst other staff, the level of } \\
\text { conversations about what Taking Part } \\
\text { is have increased ... tenfold, } \\
\text { twentyfold. It's unbelievable.' } \\
\text { 'It's certainly made my relationships } \\
\text { with colleagues, both around the } \\
\text { organisation and at national office, } \\
\text { much stronger' } \\
\text { 'The project is so tied in with the work } \\
\text { which I'm doing in [my] office ... the } \\
\text { work I've done on the project has } \\
\text { actually informed the way that I'm } \\
\text { working anyway' }\end{array}$ & $\begin{array}{l}\text { - Focus on project management } \\
\text { success was combined with focus } \\
\text { on longer-term project success } \\
\text { Despite pressure to focus on the } \\
\text { Government's public service } \\
\text { agreement targets, ACE did not } \\
\text { define the project's objectives } \\
\text { solely in terms of the specific } \\
\text { objectives set by the Government } \\
\text { By the end of the period of this } \\
\text { research there was evidence of } \\
\text { longer-term project success, i.e. } \\
\text { the project's results were } \\
\text { beginning to influence thinking } \\
\text { across the organisation } \\
\text { There was also evidence of longer } \\
\text { term benefits through the } \\
\text { development of project } \\
\text { participants' personal networks } \\
\text { across the organisation and } \\
\text { organisational learning from } \\
\text { project experience }\end{array}$ \\
\hline
\end{tabular}




\begin{tabular}{|l|l|l|}
\hline Projects & Informants' Comments & Observations \\
\hline $\begin{array}{l}\text { Disability Equality } \\
\text { Scheme }\end{array}$ & $\begin{array}{l}\text { 'There's a legal requirement; we have } \\
\text { to do this work.' }\end{array}$ & $\begin{array}{l}\text { There was a strong focus } \\
\text { throughout on achieving project } \\
\text { management success }\end{array}$ \\
& $\begin{array}{l}\text { '... we are seen as one of the leading, } \\
\text { if not the leading organisation in this' } \\
\text { The project objectives came to be } \\
\text { focused sharply on achieving } \\
\text { statutory compliance, with limited } \\
\text { attention to wider ACE purposes } \\
\text { to put a toe in the water [as regards } \\
\text { mainstreaming disability equality] ...' }\end{array}$ & \begin{tabular}{l} 
\\
\hline
\end{tabular} \\
\hline
\end{tabular}

The data in Table 4 illustrate how each of the three projects examined in this research achieved 'project management success'. They were all initiated to produce specific, tangible outputs within defined timeframes and they all achieved that. At the same time each of the projects was directed towards a strategic and cultural reorientation of ACE towards the 'demand side' and away from the 'supply side' of the arts. Moreover, while ACE adopted project management methods in order to achieve specific business objectives, it also saw project-based working as a means of facilitating teamwork across its multi-site organisation and making full use of its people's talent and expertise. As such ACE was looking for a legacy from its projects in terms of enhanced capabilities in, and orientation towards, collaborative working across the organisation.

There were clear differences between the three projects in the way in which managers balanced the pressure to achieve project management success with that to achieve project success. Managers planned a sequence of activity on the Arts Debate, involving a period of sharp focus on project management success to be followed by focus on project success. The Arts Debate was nevertheless already showing evidence of longer-term results during the period of this research, for example the indications of its influence on the corporate planning process in Table 4, reflecting the Chief Executive's commitment to it and reinforcement from the national office review. Some of the potential benefits of organisational learning from the project, however, were lost as a result of staff losses associated with the fixed-term appointment of the project manager and restructuring through the national office review.

There was evidence also of longer term successes from the Taking Part project. This was influencing thinking throughout the organisation and, as the data in Table 4 illustrate, project participants were reporting benefits in terms of their own learning from the project and of development of their personal networks across the organisation.

As in the case of the Arts Debate project, managers initially focused on the project management success of the Disability Equality Scheme project, again to be followed by focus on project success. There was less evidence at the end of this research, however, of progress towards the project success of the Disability Equality Scheme project. This contrast may in part be explained by the Chief Executive's direct sponsorship of the Arts Debate project, but it may in part be explained too by the comparison with the Taking Part project illustrated in Table 4. Managers of the Taking Part project deliberately broadened their aims beyond simply meeting the short-term targets set by the Government, so as to balance focus on meeting project-specific objectives with focus on longer term 
benefits. By contrast managers of the Disability Equality Scheme project focused specifically on statutory compliance.

Pettigrew (1979) and Smircich \& Morgan (1982) highlight the role of leaders in managing the meaning of events as a key factor in mobilising energy for change. These case studies illustrate how the way in which managers balance focus on project management success (project management perspective) with focus on project success (change management perspective) affects their ability to manage the meaning of events. Managers were able to present the Taking Part project as an exciting, long-term endeavour to increase participation in the arts, but managers of the Disability Equality Scheme project were less successful in motivating people through their narrower focus on compliance with a statutory obligation.

\section{Conclusion}

Research into managers' use of project management methods to support action specifically to bring about organisational and cultural change in their own enterprises is sparse, despite their widespread use in this context. The belief that a change initiative is more focused and assured of success when undertaken as a project often embodies a range of contestable assumptions - that a change project has a degree of legitimacy that overrides competing organisational priorities; that a change project will move the organisation in the desired direction irrespective of the overall change landscape within which it is set; and that it will necessarily benefit the organisation so long as it achieves the project objectives specified at its outset.

Despite the benefits that project management methods provide to practitioners, excessive commitment to the orthodoxies of traditional project management can become a straitjacket. It can lead to focus on project tasks 'crowding out' the engagement with stakeholders without which effective support for implementation may be lacking; to managers being too cautious to attempt change programmes that are ambitious enough to make a real difference; and to preoccupation with being seen to achieve specified project objectives distracting managers' attention away from the strategic purposes towards which those objectives were directed. The perspective of project management and change management as a duality has promise as a basis for more flexible use of project management methods in managing organisational change. This includes explicitly accommodating the need to improvise during the course of a change process, in the interests of improving stakeholder engagement or achieving broad strategic aims that may not be captured in a project initiation document, and to take risks in order to implement a change programme with sufficient scope to make a real difference. A key implication of this perspective is that managers should be wary of claiming greater certainty about how a change can be managed than they can realistically have, and should build flexibility into their plans to accommodate necessary improvisation.

The case studies set out in this paper provide some limited insights into the potential for dualities thinking as a means of combining 'how to' knowledge of the sort that project management offers with the 'what is' knowledge embedded in the change management literature (Pettigrew et al., 2001). As Hughes (2011) observes, writers often claim high failure rates for organisational change projects, but on the basis of insubstantial evidence. These claims may well mask well-judged, practical decisions to depart from agreed project plans in the interests of responding effectively to emerging events in the course of change processes. Research into project management/change 
management as a duality, and into subsidiary, underlying dualities, could explain some of these apparent failures at a deeper level, and provide useful lessons in how to adapt traditional project management methods to the complexities and uncertainties of organisational change.

Acknowledgements: I thank Dr Laszlo Czaban of Manchester Business School who supervised the research on which this paper is based, and Professor David Gray of the University of Greenwich who provided extensive comments on early drafts of this paper. I also thank the staff of Arts Council England who provided the research access that made it possible to undertake this research. 


\section{References}

ABRAHAMSON, E., 2000, Change without pain, Harvard Business Review, 78 (4), 75-79.

ARKSEY, H. \& KNIGHT, P. 1999, Interviewing for Social Scientists. London: Sage Publications.

ARTS COUNCIL ENGLAND, 2012, Organisation Review: Final Operating Model and Organisation structure, available from www.artscouncil.org.uk/media/uploads/pdf/Organisation Review presentation final.pdf, accessed on 17 March 2015.

BRAUN, V. \& CLARKE, V., 2006, Using thematic analysis in psychology, Qualitative Research in Psychology, 3(2), 77-101.

COOKE-DAVIES, T., 2002, The 'real' success factors on projects, International Journal of Project Management, 20 (3), 185-190.

DE WIT, A., 1988, Measurement of project success. Project Management, 6 (3), 164-170.

FENTON, E. \& PETTIGREW, A.M., 2000, Theoretical Perspectives on New Forms of Organising, in PETTIGREW, A.M. \& FENTON, E., The Innovating Organisation, London: SAGE, 1-46.

FREEMAN, R. E., 1984, Strategic management: A stakeholder approach, Boston: Pitman.

GALBRAITH, J. R., 1971, Matrix Organisation Designs: How to combine functional and project forms, Business Horizons, 14 (1), 29-40.

GANN, D.M. \& SALTER, A.J., 2000, Innovation in project-based, service-enhanced firms: the construction of complex products and systems, Research Policy, 29, 955-972.

GRAETZ, F. \& SMITH, A.C.T., 2010, Managing Organisational Change: A Philosophies of Change Approach, Journal of Change Management, 10(2), 135-154.

GRAY, D.E., 2014, Doing Research in the Real World (3 ${ }^{\text {rd }}$ edition), London: SAGE.

HAKIM, C., 2000, Research Design: Successful designs for social and economic research. London: Routledge.

HEROLD, D.M., FEDOR, D.B. \& CALDWELL, S.D., 2007, Beyond change management: a multilevel investigation of contextual and personal influences on employees' commitment to change, Journal of Applied Psychology, 92(4), 942-951. 
HUGHES, M., 2011, Do 70 Per Cent of All Organisational Change Initiatives Really Fail?, Journal of Change Management, 11(4), 451-464.

JOHNSON, B., 2014, Reflections: A Perspective on Paradox and its Application to Modern Management, The Journal of Applied Behavioural Science, 50(2), 206-212.

LARSON E.W. \& GOBELI, D.H., 1987, Matrix Management: Contradictions and Insights, California Management Review, 29 (4), 126-138.

LEYBOURNE, S., 2006, Improvisation within the Project Management of Change: Some Observations from UK Financial Services, Journal of Change Management, 6(4), 365-381.

LITTAU, P., JUJAGIRI, N.J. \& ADLBRECHT, G., 2010, 25 Years of Stakeholder Theory in Project Management Literature (1984-2009), Project Management Journal, 41 (4), 17-29.

LUNDIN. R.A. \& SÖDERHOLM, A., 1995, A Theory of the Temporary Organisation. Scandinavian Journal of Management, 11 (4), 437-455.

MASSINI, S. \& PETTIGREW, A.M., 2003, Complementarities in Organisational Innovation and Performance: Evidence from the INNFORM Survey, in PETTIGREW, A.M., WHITTINGTON, R., MELIN, L., SANCHEZ-RUNDE, C., VAN DEN BOSCH, F.A.J., RUIGROK, W. \& NUMAGAMI, T., Innovative forms of Organising. London: SAGE, 133-172.

MCLEOD, L., DOOLIN, B. \& MACDONNELL, S.G., 2012, A Perspective-Based Understanding of Project Success, Project Management Journal, 43 (5), 68-86.

MILGROM P. \& ROBERTS J, 1995, The Economics of Modern Manufacturing Technology, Strategy, and Organisation. The American Economic Review, 80(3), 511-528.

MINTZBERG, H., 1983, Structure in Fives: Designing Effective Organisations, Prentice-Hall International, Inc.

OFFICE OF GOVERNMENT COMMERCE, 2009, Managing Successful Projects with PRINCE2, London: The Stationery Office.

PETTIGREW, A.M., 1979, On studying organisational cultures, Administrative Science Quarterly, 24(4), 570-581.

PETTIGREW, A.M., 2012, Context and Action in the Transformation of the Firm: A Reprise. Journal of Management Studies, 49(7), 1304-1328. 
PETTIGREW, A.M. \& WHIPP, R., 1991, Managing Change for Competitive Success, Oxford: Blackwell. PETTIGREW, A.M. \& WHITTINGTON, R., 2003, Complementarities in Action: Organisational Change and Performance in BP and Unilever 1985-2002, in PETTIGREW, A.M., WHITTINGTON, R., MELIN, L., SANCHEZ-RUNDE, C., VAN DEN BOSCH, F.A.J., RUIGROK, W. \& NUMAGAMI, T., Innovative forms of Organising. London: SAGE, 173-207.

PETTIGREW, A.M., WOODMAN, R.W. \& CAMERON, K.S., 2001, Studying Organisational Change and development: Challenges for Future Research, Academy of Management Journal, 44(4), 697-713.

SANCHEZ-RUNDE, C.J. \& PETTIGREW, A.M., 2003, Managing Dualities, in PETTIGREW, A.M., WHITTINGTON, R., MELIN, L., SANCHEZ-RUNDE, C., VAN DEN BOSCH, F.A.J., RUIGROK, W. \& NUMAGAMI, T., Innovative forms of Organising. London: SAGE, 243-250.

SAUNDERS, M., LEWIS, P. \& THORNHILL, A., 2012, Research Methods for Business Students, Harlow: Pearson.

SINCLAIR, A., 1995, Arts and Cultures: The History of the 50 Years of the Arts Council of Great Britain. London: Sinclair-Stevenson.

SMIRCICH, L. \& MORGAN, G., 1982, Leadership: The Management of Meaning. The Journal of Applied Behavioural Science, 18(3), 257-273.

SUTHERLAND, F. \& SMITH, A.C.T., 2013, Leadership for the age of sustainability: A Dualities Approach to Organisational Change, in BY, R.T. \& BURNES, B. (eds.), Organisational Change, Leadership and Ethics: Leading Organisations towards Sustainability (pp.216-239), London: Routledge.

TURNER, J.R., 1999, The Handbook of Project-based Management (Second Edition). London: McGraw-Hill.

TURNER, J.R. \& KEEGAN, A., 1999, The Versatile Project-based Organization: Governance and Operational Control. European Management Journal, Vol. 17, No. 3, pp. 296-309.

WHITFORD, A.B., 2006, Unitary, Divisional and Matrix Forms as Political Governance Systems. Journal of Management Governance, 10, 435-454.

WINTER, M., SMITH, C., MORRIS, P. \& CICMIL, S., 2006. Directions for future research in project management: The main findings of a UK government-funded research network. International Journal of Project Management. 24 (8), 638-649 
WITTS, R., 1998, Artist Unknown: An Alternative History of the Arts Council. London: Little, Brown and Company (UK).

YIN, R.K., 2003, Case Study Research: Design and Methods (3 ${ }^{\text {rd }}$ edition), London: SAGE Publications. 